\title{
JUSTICE JEAN E.L. CôTÉ: Keeping The "Civil" in Civil Procedure
}

\author{
Barbara BillingSley* ${ }^{*}$ And The HonOuRABle Justice June Ross ${ }^{* *}$ \\ PANEL MODERATOR: ViVIAN R. STEVENSON, Q.C. ${ }^{* * *}$
}

\section{REMARKS: BARBARA BILLINGSLEY}

\section{A. INTRODUCTION}

My initial intention for this presentation was to identify a handful of judgments which best illustrate the significance and enduring nature of Justice Côté's contributions to the law of civil procedure in Alberta. I do not know what I was thinking. As a scholar of civil procedure, I should have known that this task would be the exact opposite of looking for a needle in a haystack. Justice Côté is renowned for his expertise on civil litigation process and for his writings on the subject. ${ }^{1}$ The difficulty with commenting on Justice Côté's contributions to civil procedure jurisprudence is not a lack of material to draw from; the problem lies in deciding which of the many worthy judgments to highlight as representative of his work in the area.

So, cognizant of the time constraints of this symposium, I have decided to make things easier on myself by taking a slightly different route. Instead of attempting to convince you that I have somehow divined the most significant of Justice Côté's many civil procedure rulings, I will offer instead a temporal sampling of those judgments. Justice Côté's 28 years as a member of the Alberta Court of Appeal spanned four decades, from the 1980s to the 2010s. So, to illustrate Justice Côté's contributions to the law of civil procedure, I will focus on four cases, one from each of those four decades. The cases are: Crothers v. Simpson Sears Ltd. ${ }^{2}$ from 1988; Dorchak v. Krupka ${ }^{3}$ from 1997; Balm v. 3512061 Canada Ltd. ${ }^{4}$ from 2003; and Paniccia Estate v. Toal ${ }^{5}$ from 2012.

These particular cases have several features in common. First, they are all decisions in which Justice Côté wrote the reasons for a unanimous court. Second, they have all been, and

\footnotetext{
Professor, University of Alberta. Her current areas of research and teaching include insurance law, civil litigation processes, and constitutional law issues pertaining to private law matters.

Justice of the Alberta Court of Queen's Bench. Justice Ross practiced civil litigation in Edmonton from 1980 to 1988 , when she joined the Faculty of Law at the University of Alberta. As an academic and teacher, Justice Ross specialized in constitutional law and civil procedure. From 1999 to 2001 she was associate dean of the Faculty, and from 2001 to 2003 she was seconded to the Alberta Law Reform Institute as lead counsel to the Alberta Rules of Court Project.

*** $\quad$ Partner, Duncan Craig LLP. Vivian has practiced mainly in the area of civil litigation since her admission to the Bar of Alberta in 1990. She was privileged to have the Honourable Justice Jean E.L. Côté serve as one of her principals during her articles. The main focus of her practice has been in the area of insurance and tort litigation, defending claims relating to professional negligence, property damage, and personal injury and in providing coverage advice.

The Honourable Justice Russell Brown \& Annalise Acorn, "Beware of Tiger: The Logic of Justice Jean E.L. Côté's Tort Law" (2019) 56:4 Alta L Rev at 1235. In addition to issuing numerous civil procedure judgments, Justice Côté is a co-author (with the Honourable Justice William A Stevenson) of the multivolume Civil Procedure Encyclopedia (Edmonton: Juriliber, 2003) and the Alberta Civil Procedure Handbook, published annually by Juriliber.

1988 ABCA 155 [Crothers].

1997 ABCA 89 [Dorchak].

2003 ABCA 98 [Balm].

2012 ABCA 397 [Paniccia]. This case is also discussed in Brown \& Acorn, supra note 1.
} 
continue to be, frequently cited by Alberta courts. In fact, according to Quicklaw, up to the end of 2018, these four cases have been referenced by Alberta courts a combined total of 249 times, ${ }^{6}$ including 49 times in the past two years alone, with each of the cases having been cited more than once in that time period. ${ }^{7}$ (They have also been regularly cited by courts outside of Alberta, though I didn't count those cases). While the significance of case law is not demonstrated by citation rates alone, these numbers offer a rudimentary measure of the enduring legacy of Justice Côté's contributions to the law of civil procedure in this province. The continued citation of these cases in recent years is particularly notable because three of the four judgments were issued on the basis of Alberta's former Rules of Court. ${ }^{8}$ As many of you know, Alberta implemented fully revised Rules of Court in $2010 .^{9}$

Finally, and most importantly, as I hope to demonstrate in this discussion, each of these decisions reflect three overlapping themes which I believe are inherent in all of Justice Côté's civil procedure judgments. The themes I am referring to are:

- first, that civil litigation, and therefore civil procedure, is a critical aspect of our legal system, designed to provide a fair and just method of resolving disputes among private parties;

- $\quad$ second, that civil procedure works in the service of substantive law and should be applied as such; and

- third, that the rules of civil procedure must be applied in a principled manner, not only to remedy the conflict between the parties in a given case, but to advance and contribute to the overall purpose and operation of the civil justice system.

In the cases I have selected, these themes are elucidated from Justice Côté's purposive and practical analysis of the procedural rules in dispute. This down-to-earth, no-nonsense approach is a dominant, if not the dominant, feature of Justice Côté's civil procedure judgments. ${ }^{10}$ It is a methodology that ensures that the Rules of Court are applied in a meaningful and predictable way, consistent with the purpose and function of civil procedure as a whole. To borrow Justice Côté's own words, it "avoid[s] sterile abstract theorizing" about procedural issues. ${ }^{11}$ In my view, it keeps civil procedure civilized.

With these ideas in mind, I now turn to a review of the cases.

This data is from a "citing cases" search I conducted on Quicklaw Advance, LexisNexis.ca on 2 January 2019 in relation to each of the four selected cases. The search results indicated that, up to 31 December 2018, reported judgments from Alberta courts had cited Crothers, supra note 2, 61 times; Dorchak, supra note 3, 41 times; Balm, supra note 4, 128 times; and Paniccia, ibid, 19 times.

$7 \quad$ Ibid. The search results indicated that, between 1 January 2017 and 31 December 2018, reported judgments from Alberta courts had cited Crothers, ibid, 2 times; Dorchak, ibid, 6 times; Balm, ibid, 32 times; and Paniccia, ibid, 9 times.

Alberta, Rules of Court, AR 390/1968 [Rules of Court (1968)].

Alberta, Rules of Court, AR 124/2010 [Rules of Court (2010)].

As suggested by Brown \& Acorn, supra note 1 at 1236 , this common sense approach is also characteristic of Justice Côté's tort law jurisprudence.

Crothers, supra note 2 at para 4. 


\section{B. Selected Cases}

\section{CROTHERS V. SIMPSON SEARS LTD.}

In this case, an out-of-province plaintiff appealed a Court of Queen's Bench Order requiring him to post $\$ 1,300$ in security for costs. The appellant argued that Alberta's security for costs rule $\mathrm{e}^{12}$ unjustifiably violates the Canadian Charter of Rights and Freedoms ${ }^{13}$ by unduly infringing upon a litigant's equality and mobility rights. ${ }^{14}$ The court rejected this argument and dismissed the appeal.

The judgment in Crothers was issued on 10 May 1988, when Justice Côté was still new to his judicial role, having been appointed to the Court of Appeal in 1987, directly from practice. It was also a time when the Canadian Charter of Rights and Freedoms, and particularly the equality provision set out in section 15 of the Charter, was in its infancy as part of Canada's written constitution..$^{15}$ Looking at the Crothers case today, Justice Côté's judgment is illustrative of the thorough and incisive approach to civil procedure issues that marks his judicial career. It is also remarkably prescient of the future development of Charter law.

Justice Côté began this judgment by discussing "how security for costs works." ${ }^{16}$ He noted that most of civil procedure "balances the interests of both parties, plaintiff and defendant"17 and that the security for costs rule achieves this balance by giving the court broad discretion to grant or refuse the application and to set parameters for the value, manner, and time for the posting of security. He explained that the rule calls upon the court to consider relevant practical factors, such as the merits of each party's case, the financial means of the plaintiff, how much time is allowed for posting security, and the consequences imposed by a failure to post security. In the context of the Crothers case, Justice Côté's stated reason for providing this detailed explanation of the security for costs rule was to provide a "factual [underpinning]"18 for the constitutional analysis. In a broader sense, however, the explanation stands alone as a leading authority on the purpose and operation of the security for costs rule.

As for the Charter arguments, Justice Côté concluded that the security for costs rule did not offend the Charter's equality or mobility protections. At the time, the Supreme Court had not yet ruled on the proper test for assessing equality rights under the Charter. Nonetheless, anticipating future Supreme Court findings, Justice Côte cut to the heart of the matter, holding that, however equality is defined, "the maximum extent of forbidden discrimination must involve a less favourable legal position because of some insufficient criterion." 19

At the time this case was decided, the relevant rule was rule 593(1) of the Alberta, Rules of Court (1968), supra note 8. It is currently rule 4.22 of the Alberta, Rules of Court (2010), supra note 9.

Part 1 of the Constitution Act, 1982, being Schedule B to the Canada Act 1982 (UK), 1982, c 11 [Charter].

Ibid, ss 15(1), 6(2), respectively.

With the exception of section 15, the Charter took legal effect on 17 April 1982. The equality guarantee in section 15 came into force on 17 April 1985. See Government of Canada, "Guide to the Canadian Charter of Rights and Freedoms," online: $<$ https://www.canada.ca/en/canadian-heritage/services/howrights-protected/guide-canadian-charter-rights-freedoms.html >.

Supra note 2 at para 4.

Ibid at para 5.

Ibid at para 4.

Ibid at para 39. 
Applying this criteria, Justice Côté held that the security for costs rule does not treat nonresidents less favourably than residents because non-residence is not the sole determining factor for awarding security for costs. Along similar lines, Justice Côté held that the security for costs rule does not run afoul of the Charter's mobility guarantee because the rule "does not govern where one may live or work; it is about when one should make assets available to sue. ${ }^{20}$ Finally, Justice Côté held that, even if the alleged Charter rights were violated, the security for costs rule was justified as a reasonable limit under section 1 of the Charter. In his section 1 analysis, Justice Côté emphasized the importance of civil litigation processes in Canadian society as follows:

I repudiate the suggestion that a free and democratic society's objectives ignore civil lawsuits. Every citizen of a free and democratic society expects, and must get, justice in his dealings with his fellow citizens. A fair system of justice to settle private disputes among subjects has been a prime public objective of civilized societies whose traditions Canada follows. ${ }^{21}$

\section{DORCHAK V. KRUPKA}

This decision concerns the proper description of documents in what was then called an Affidavit of Documents, known today as an Affidavit of Records. ${ }^{22}$ The appellants had each provided Affidavits describing the producible and privileged documents only as numbered documents (for example, as "[d] ocuments mechanically numbered 000001 to 0000020 "). ${ }^{23}$ The respondent applied for a further and better Affidavit providing the "nature, date, name of author, and name of recipient" for each document. ${ }^{24}$

Noting that existing authorities conflicted on the point, Justice Côté set out to clarify the law regarding the proper description of documents in an Affidavit of Documents. His judgment on this issue epitomizes his judicial pattern of grounding a practical resolution in a contextual analysis of the purpose or intention of litigation procedures. He began by considering the purpose of pre-trial documentary disclosure, explaining that the "discovery of documents" is "a valuable mechanism invented in Chancery ... to prevent destruction or suppression of evidence, get admissions for trial, prevent surprise, and prevent fabrication of written or oral evidence. ${ }^{25}$ He then went on to translate this objective into practical terms. He said:

An affidavit of documents must show unambiguously what documents' existence it does or does not disclose. It must remove any uncertainty on the following vital question. If a piece of paper turns up later, or is tendered on a motion or at trial, has it been disclosed by the previous affidavit of documents? ${ }^{26}$

On this basis, he concluded that, for both privileged and producible documents, the law requires only that each document be described in a way which makes it unmistakably identifiable. Indelible numbering of each document is sufficient to satisfy this requirement.

Ibid at para 46.

Ibid at para 49 [emphasis in original].

See Rules of Court (2010), supra note 9, Part 5, Subdivision 2.

Supra note 3 at para 4 .

Ibid.

Ibid at para 7 .

Ibid at para 8 . 
In regards to producible documents in particular, Justice Côté postulated that any further detail in the description of documents is a matter of "mechanics, convenience and common sense," 27 not law. In other words, the appropriate level of detail used to describe the documents depends on pragmatic factors such as the number of documents and the complexity of the lawsuit. Justice Côté cautioned, however, that the description of producible documents should always be guided by the underlying purpose of simplifying litigation. Here again, Justice Côté's propensity for balancing the interests of litigants with reference to the purpose of litigation procedures was evident. He stated that documentary disclosure should not be treated as "busywork, or a matter of form," ${ }^{28}$ but neither should it require "pointless work or unnecessarily cumbersome methods." 29 As vividly explained by Justice Côté, "We should be streamlining litigation, not burdening it with mystic incantations and ceremonies." ${ }^{30}$

Justice Côté's judgment in this case also revealed him to be a champion of the principle of privilege, once again prescient of later Supreme Court of Canada rulings which reinforced the fundamental importance of privilege in the civil justice system. ${ }^{31}$ Noting that privilege is a matter of substantive law and that "[s]ubstantive law (privilege) drives procedure (the affidavit), not vice versa," 32 he concluded that "[a]ny system of listing or describing privileged documents which gives away privileged information is therefore unthinkable." 33 After thoroughly reviewing existing authorities, Justice Côté rejected the suggestion that the description of privileged documents must include "dates, contents, or parties to them." ${ }^{34} \mathrm{He}$ held instead that, beyond identifying them by number, the issue of how these documents are most usefully described without disclosing privileged information is ultimately "a question of practicality," ${ }^{35}$ although an affidavit must always clearly indicate "which papers fall within which" of the "three kinds of privilege (solicitor's advice, litigation, and withoutprejudice)." 36

Since the passage of Alberta's revised Rules of Court in 2010, the Alberta Court of Appeal has revisited the requirements for describing privileged documents to specify additional disclosure requirements. However, in doing so, the Court was mindful of Justice Côté's comments about the importance of protecting privileged information. As expressly stated by the Court, "much of what was said in Dorchak still has resonance.",37

Ibid.

Ibid.

See e.g. Alberta (Information and Privacy Commissioner) v University of Calgary, 2016 SCC 53; Lizotte v Aviva Insurance Company of Canada, 2016 SCC 52; Union Carbide Canada Inc v Bombardier Inc, 2014 SCC 35.

Dorchak, supra note 3 at para 35 [emphasis in original].

Ibid at para 36 .

Ibid at para 43.

Ibid at para 62.

Ibid at para 67.

Canadian Natural Resources Ltd v ShawCor Ltd, 2014 ABCA 289 at para 55. 


\title{
3. BALM V. 3512061 CANADA LTD.
}

As recently characterized by Justice Topolniski of the Alberta Court of Queen's Bench, this decision is the leading Alberta authority on the amendment of pleadings. ${ }^{38}$ In this case, two original defendants in the action appealed a court order permitting the plaintiff to amend its Statement of Claim to add three new defendants after pleadings had closed. In the result, the Court of Appeal allowed the appeal in part, the details of which are not pertinent for today's discussion. For present purposes, what is relevant is the analysis which Justice Côté brought to the problem.

The essential argument of the appellants was that the plaintiff had insufficient evidence to support the amended claims. Characteristically, Justice Côté addressed this argument by considering the court's authority to grant an amendment in the context of the purpose of pleadings and the standards imposed by related procedural rules. He noted that the avoidance of multiplicity by encouraging joinder of claims is "fundamental to our civil procedure" ${ }^{39}$ and that the rules for pleading, in the initial instance, require "no evidence at all." ${ }^{40} \mathrm{He}$ concluded that these factors militate in favour of permitting amendments prior to the expiration of a limitation period, even if the amendments include new causes of action. Further, Justice Côté noted that an amendment may be allowed even if it includes a doubtful plea. He found that, where the doubtful amended plea overlaps with "clearly arguable" claims, disallowing the amendment "produces a real risk of injustice (if the new claim is actually open in law), but no real advantage (even if it is bad in law)." ${ }^{.11}$ Accordingly, an application to amend does not need to meet the evidentiary standard of a summary judgment application. Instead, for the sake of consistency and practicality, the appropriate test should be "very similar to that for striking out pleadings" 42 or for service ex juris, where the plaintiff only needs to demonstrate a reasonable basis for the claim. As summarized by Justice Côté:

\begin{abstract}
All of these analogies confirm ... that a modest degree of evidence justifies an amendment to pleadings within the limitation period. And the analogies show that requiring a stiffer test to amend would be pointless, producing little or no practical result. To require a stiffer standard for evidence to amend would produce a motion for summary judgment in favour of the defendant, without requiring that the defendant swear to anything. That is contrary to all principle. ${ }^{43}$
\end{abstract}

This passage in particular demonstrates Justice Côté's holistic approach to civil procedure issues and his insistence on developing the law of civil procedure as a consistent and integrated whole.

\section{PANICCIA V. TOAL}

This case raised two civil procedure issues. The first issue was whether the trial judge properly refused to consider two arguments that were not in the defendant's pleadings and grounds $2018 \mathrm{ABCA} 144$.

Balm, supra note 4 at para 28 .

Ibid.

Ibid at para 14 .

Ibid at para 12

Ibid at para 29 . 
that were raised by the defendant for the first time in its final argument after the close of evidence at trial. The second issue was whether the trial judge was justified in awarding the plaintiff double costs on a full-indemnity basis. Justice Côté resolved these issues in favour of the plaintiff, characteristically referencing the purpose, context, and practical operation of the relevant procedural rules.

In holding that the trial judge properly refused to consider arguments that had not been pled by the defendants, Justice Côté drew upon fundamental principles of civil litigation procedure. He recognized, as a "simple application of the first rule of natural justice, that each party have notice of the opposing party's case, and a fair chance to counter it." ${ }^{44} \mathrm{He}$ further acknowledged that "pleadings do matter" for the purpose of providing that notice and that "a judgment based on an issue not pleaded is improper." 45 Finally, once again demanding logical integration of procedural rules, Justice Côté noted that, if the defendant had attempted to amend its defence pleading to add the new issues, "the usual principles for amendment" 46 would apply, including the "elementary" principle that "pleadings cannot be amended late if the amendment would cause the opposing party prejudice not compensable in costs. ${ }^{" 47}$ He held that a defendant should not be permitted to sidestep these considerations by asking the court to consider the new arguments without applying to amend the defendant's pleadings.

In regards to the issue of costs, Justice Côté focused on the judicial discretion afforded by Alberta's rules of procedure. He noted that, while "in principle solicitor-client costs should not be commonly awarded ... in Alberta (and elsewhere) there is a very well-settled rule which gives a judge discretion to award larger than usual, even solicitor-client, costs for significant misconduct during litigation. ${ }^{, 48}$ For the same reason, he rejected the defendant's argument that double costs cannot be awarded on the basis of the rejection of an informal, as opposed to a formal, offer. Justice Côté held that the fact that the rules expressly allow for double costs to be awarded in the context of a formal offer does not restrict the court's discretion to award such costs in the context of an informal offer. These findings on costs demonstrate Justice Côté's respect for interpreting the Rules of Court, not only in a purposive context but also as they are written. This might seem like an obvious approach, but it is nonetheless essential to ensuring consistency and predictability in civil procedure law.

\section{CONClusion}

The four cases I have reviewed are not a statistically significant sampling of Justice Côté's civil procedure decisions. They are a drop in the bucket. Nonetheless, I believe that they are collectively representative of Justice Côté's approach to civil procedure law during his time on the Alberta Court of Appeal. In addition to establishing or reinforcing principles about the particular rules at issue, these judgments provide a template for interpreting procedural rules. They demonstrate Justice Côté's commitment to the interpretation of civil procedure rules in a purposeful, consistent, logical, practical, and principled manner.

Paniccia, supra note 5 at para 37.

Ibid at para 32 .

Ibid at para 33.

Ibid at para 30.

Ibid at para 135 . 
About a year before Justice Côté's retirement from the Court, the Supreme Court of Canada issued its seminal ruling in Hryniak v. Mauldin. ${ }^{49}$ In this decision, the Supreme Court called for a litigation culture shift, redirecting the focus of litigation from resolution via trial to judicial resolution by the most fair and efficient means possible. This new focus has been adopted in Alberta ${ }^{50}$ and, in my opinion, it makes Justice Côté's purposive and practical approach to the rules all of the more necessary and instructive. Without the preparation or conduct of trial as a benchmark, it is critically important that the Rules of Court be interpreted and applied in accordance with a principled understanding of their purpose in facilitating judicial resolution. The foundational litigation principles and the principles of consistency, logic, and practicality championed by Justice Côté are instructive for defining that purpose. Regardless of what changes might be made to the rules in future, Justice Côté's rulings endure as lessons about how procedural law should be made.

I would like to end my comments on a personal note. In his 2017 convocation address at the University of Alberta, Justice Côté spoke about the lasting impact of inspired or passionate teachers. ${ }^{51}$ For several years, I have aspired to be a passionate instructor of civil procedure, but Justice Côté sets the standard. I have never met anyone more passionate about civil procedure, or about the enterprise of educating others about civil procedure, than Justice Côté. I consider myself fortunate to know him and, along with many others, to have benefited from his extraordinary knowledge of this important area of law.

\section{REPLy: The Honourable Justice June Ross}

My reply will be an addendum rather than a true reply. I know a good case when I hear one, and Professor Billingsley's themes, and examples, are irrefutable.

As an addendum, I thought I would pick up on the theme introduced by Professor Billingsley of the litigation culture shift introduced by Hryniak ${ }^{52}$ and the importance of Justice Côté's purposive and practical approach to procedural rules in light of a changing landscape. The redirection in dispute resolution from trial to other means recognizes the need for more efficient use of limited resources, without sacrificing essential fairness.

A primary challenge faced by the courts today is a shortage of court resources and resulting delays in the administration of justice. The criminal law implications of this - in $R$. v. Jordan ${ }^{53}$ and its progeny - are well-known. In family law, the need to use resources efficiently and to accommodate the increasing number of self-represented litigants has been, and will no doubt continue to be, the genesis of innovative procedures designed to encourage and facilitate early resolution of disputes. In civil litigation, where so much occurs outside the courthouse, the impact of change may be harder to detect or describe, but it is certainly being felt.

See Barbara Billingsley, "Hryniakv. Mauldin Comes to Alberta: Summary Judgment, Culture Shift, and the Future of Civil Trials" (2017) 55:1 Alta L Rev 1.

See University of Alberta, Faculty of Law, "Honour Your Teachers, Urges Leading Judge in Convocation Address"(22 November 2017), online: $<$ https://ualberta.ca/law/about/news/alumni-news/ $2017 /$ november/jean-cote>. 
I will mention two areas in which these forces are having a particular impact in the Alberta courts in which Justice Côté's guidance has a significant and ongoing influence.

One relates to Master's appeals and the standard of review. In Alberta, traditionally and under the 2010 revised Rules of Court, the standard of review of a Master's decision on appeal to the Court of Queen's Bench is correctness. Rule 6.14 provides that the appeal "is an appeal on the record of proceedings before the master and may also be based on additional evidence that is, in the opinion of the judge hearing the appeal, relevant and material.," ${ }^{54}$

The standard of review under the new rule was considered by the Court of Appeal in Bahcheli v. Yorkton Securities Inc. ${ }^{55}$ Prior to this decision, a number of Queen's Bench judges had held that the standard of review under the new rule was deferential.

Bahcheli shares the characteristics of Justice Côté's procedural decisions discussed by Professor Billingsley: it is a decision in which Justice Côté wrote the reasons for a unanimous court, it has been cited by Alberta courts on numerous occasions, and it reflects the themes of all of Justice Côté's civil procedure judgments.

Justice Côté introduced the issue with his usual directness and clarity:

The big issue in this judgment is the standard of review on appeal from a master to a judge. Terminology is not completely consistent for the standard of review which was adopted by the Alberta Courts before the new Rules came into force. It is sometimes called non-deferential, and sometimes called an appeal de novo. But more commonly the term used is "correctness."

Justice Côté organized his reasons under two headings.

First heading: "Do the Rules Set the Standard of Review?" In other words: "The place to start is the wording of the new Rules. If they clearly addressed the standard of review on appeal to a judge, that would end the question." 57

Justice Côté rejected the argument that reference to an "appeal on the record" determined the standard of review. As written, the phrase is about evidence, not the standard of review. And it is subject to a broad exception, allowing new evidence that is relevant and material. This makes a deferential standard impossible "in many cases." "At best," he concluded, "the Rules are silent." 58

Which brings us to the next heading, "What the Standard of Review Should Be." In other words: "That silence does not bar having a judge-made standard of review; it necessitates it." 59

Supra note 9.

2012 ABCA 166 [Bahcheli].

Ibid at para 3 .

Ibid at para 8 .

Ibid at para 18

Ibid at para 19. 
Justice Côté cited the Consultation Memorandum from the Alberta Law Reform Institute's Rules of Court Project, which recommended no change to the standard of review, essentially on the ground, as put by the appellant in Bahcheli, that nothing was broken that needed fixing. ${ }^{60}$ Justice Côté agreed that appeals from Masters worked well, and explained further:

A motion to a Master is not necessarily final. In theory, maybe counsel should have perfect foresight, and assemble all the evidence which might possibly be relevant, couched in clear and unmistakable language. But no human being is perfect, and sometimes justice lies on the side of letting a party later patch up oversights and ambiguities in his or her first affidavit.... Furthermore, requiring perfection the first time could well increase the net expense and delay in litigation. ${ }^{61}$

The cases in which an appeal de novo may seem to impose an undue strain on limited court resources are not typically interlocutory matters dealt with by Masters in morning chambers and, rarely, appealed to the Queen's Bench. They are summary judgment applications or applications to dismiss for delay. These are special applications, often involving an extensive record before the Master. The record may be supplemented on appeal to remedy shortfalls, which may have been helpfully pointed out by the Master. Scheduling these applications can take many months, recently up to a year, before the Master and again before the Queen's Bench judge. However, as Justice Côté pointed out, the significance of these applications may actually support a less deferential review. As to the possibility of distinguishing matters that call for different standards of review, this can be difficult, as we know from the intransigence of the issue in administrative law. As Justice Côté observed, determining this issue "would consume time and money, and would be needless litigation about litigation." ${ }^{\circ 2}$

There continues to be different views about this issue. Perhaps there will be a legislative determination of the standard of review in the future. At this time, Justice Côté's "judgemade" standard applies, having been cited in 195 Alberta decisions according to a recent CanLII search. It is a standard that reflects, as Professor Billingsley described it, an interpretation of the Rules of Court "not only in a purposive context, but also as they are written." ${ }^{63}$ Justice Côté revealed his practical and principled understanding of civil procedure in concluding that "the standard of review on appeal from a Master to a judge, on all issues, is still correctness." 64

The second issue I wish to mention relates to the dismissal of actions for delay, particularly Rule 4.33, known as the "drop dead" rule. Of course, Justice Côté has written decisions about this rule. But I also wanted to mention another contribution he has made to civil procedure, in a legislative role as the Chair of the Rules of Court Committee from 1990 to 2007 .

Justice Côté was Chair of the Rules of Court Committee during the consultation and research stage of the Alberta Law Reform Institute's Rules of Court project. I was fortunate to act as lead counsel on that project in its early days prior to my appointment to the Queen's 
Bench. Justice Côté's support for the project was vital in getting it off the ground, and was much appreciated by myself and others.

The drop dead rule is hard to get right. If it only requires that something "that materially advances the action" be done every five years (as under Rule 244.1 of the former Rules of Court), it may rightly be seen as condoning undue delay. Accordingly, the new rule required that something be done that "significantly advanced [the] action" in a two year period. ${ }^{65}$ However, with limited exceptions and no discretion in the court to extend time, some thought the new rule would result in the unfair termination of meritorious lawsuits. The Rules of Court Committee, by this time under Justice Slatter's chairmanship, heard concerns about the new provision and undertook a consultation process. This was followed by amendments to Rule 4.33, increasing the period to three years and rewriting and clarifying the rule. But the underlying concern of the rule, to deal firmly with delay, was maintained. I believe I detect Justice Côté's continuing influence. As he writes in the commentary to Rule 4.33 in the Alberta Civil Procedure Handbook, 2019, "[d]elay in a suit is anathema to all the principles of the 2010 Rules (efficiency, proportionality, and economy)." 66

Justice Côté's decisions always had a direct and pithy style. I would also like to pay tribute to his love of a good metaphor. In a speech given in 2012 on the occasion of Justice Côté's 25th anniversary with the Court of Appeal, these "Côtéisms" were celebrated. I thank Justice Slatter who shared with me his student's research regarding "Colourful phrases used by Justice Côté.” The research revealed that Justice Côté is an animal lover at heart, with repeated references to escaping horses, tail-wagging dogs, and cats out of bags. Of course, Justice Côté is not limited to the old saws we all know, as the facts become more egregious, the adages grow. So the tail does not only wag the dog, it grows "larger than the dog" ${ }^{\prime 67}$ and chases the dog "in circles." ${ }^{\circ 8}$ The horse has not merely left the stable, he was gone "five months before the appeal was even filed." "' Or the horse's escape was illusory, he was "out of the stable door," but already "saddled by his new legal owner, the trustee."70

I will end with a more recent Côtéism, from a 2015 decision of the Northwest Territories Court of Appeal, Bell Mobility Inc. v. Anderson. ${ }^{71}$ Bell claimed the contractual right to charge its customers in the Northwest Territories a \$0.75 monthly charge for 911 calling, even though there is no 911 service in the Territory. Justice Côte for the Court found that the contract, properly interpreted, did not provide for a "fee for nothing in return." 72 And just to make sure that the message was understood, he added: "In my respectful view, connecting someone to nothing is still nothing. A right to charge a door-to-door delivery fee for milk cannot be triggered by delivering empty bottles.",73

Justice Côté always delivered the goods. Thank you Justice Côté.

Alberta, Rules of Court (2010), supra note 9, r 4.33 as it appeared on 14 August 2010 to 4 November 2010.

WA Stevenson \& JE Côté, Alberta Civil Procedure Handbook, vol 1 (Edmonton: Juriliber, 2019) at 474.

KDM Management v Rushton, 1998 ABCA 217 at para 33.

$R v$ Merchant, $1991 \mathrm{ABCA} 115$ at para 8.

Winners Equities Inc v 664050 Alberta Ltd, 2006 ABCA 394 at para 31.

Clark v Law Society of Alberta, 2000 ABCA 242 at para 28, attributed to "the Court," but thought by those in the know likely to have been authored by Justice Côté.

2015 NWTCA 3.

Ibid at para 19.

Ibid at para 22 . 
[this page is intentionally blank] 